Gut, (1967), 8, 388

\title{
Exocrine pancreatic disease and the malabsorption syndrome in tropical Africa
}

\author{
J. G. BANWELL, M. R. S. HUTT, P. J. LEONARD, V. BLACKMAN, \\ D. W. CONNOR, P. D. MARSDEN, AND J. CAMPBELL \\ From the Department of Medicine and Pathology, Makerere University College, \\ Kampala, Uganda, East Africa
}

EDITORIAL COMMENT The study of malabsorption in Uganda, East Africa, has revealed that the majority of patients who have steatorrhoea suffer from exocrine pancreatic disorders. The differing incidence of malabsorption syndromes in a hospital community in Kampala, Uganda, has been compared with the incidence in both temperate and tropical climates and the clinical and laboratory features of this syndrome are discussed.

The geographical regions of tropical Africa represent the land and people south of the Sahara desert, excluding South Africa, which, in the main, lies south of the tropic of Capricorn. The major indigenous African people (Negroes, Bantu, and Hamites) are to be found in this region (Hailey, 1957).

It is probable that tropical sprue represents the major cause of malabsorption in tropical regions of the world. Intestinal tuberculosis of both the primary and the secondary variety may also be common owing to the widespread prevalence of tuberculous infections in these regions, but the frequency with which other diseases cause steatorrhoea in tropical areas is unknown. Reports of tropical sprue from Africa have been uncommon (Begg, 1912; Manson-Bahr, 1943; Gelfand, 1947; Limbos, 1956; Trowell, 1960; Harries, 1964; Gelfand, 1964), and with the exception of the two patients described by Harries, reported cases have usually represented the illness of expatriate rather than of indigenous people. The rarity of these descriptions adds confirmation to previous clinical impressions that this disease is uncommon in tropical Africa.

\section{PANCREATIC DISEASE IN TROPICAL COUNTRIES}

In recent years, there have been occasional reports of the occurrence of exocrine pancreatic disorders in tropical regions. In 1959, Zuidema described 18 patients from Indonesia with disseminated pancreatic calcification. All had a similar clinical appearance with severe malnutrition, muscle wasting, parotid gland enlargement, and hair and skin changes which resembled those seen in children with kwashiorkor. Similar features were seen in 27 other patients who were assumed to have pancreatic fibrosis without calcification. Diabetes was the presenting feature in $\mathbf{4 3}$ of the $\mathbf{4 5}$ patients. Duodenal juice was analysed from 20 patients (whether with or without pancreatic calcification was not stated) and a low lipase content was the only constantly found abnormality. Steatorrhoea was not detected. The pancreatic lesion was thought to be the result of the protein malnutrition. Shaper (1959) also described a similar clinical picture in 11 patients who had pancreatic calcification in Uganda, East Africa. Two had malabsorption syndromes with steatorrhoea and five presented with diabetes. In subsequent articles (Shaper, 1960, 1961, and 1964) the group was increased to 36 , of whom 17 presented with diabetes and five as a malabsorption syndrome. In early publications, protein malnutrition was the suggested cause for the pancreatic disease, whilst in later articles alcoholic excess was thought to induce destructive changes in the pancreas already adversely affected by nutritional imbalance. Kinnear (1963) found that a similar syndrome existed among diabetic patients in Nigeria. Thirty of 226 patients with diabetes mellitus had radiological evidence of pancreatic calcification. The patients were young $(75 \%$ under 20 years of age) and alcoholism was not an aetiological factor. The incidence of malabsorption in the series was not given: 10 patients who were studied all excreted 10-20 g. fat per day in the stools. Other similar case reports have since appeared from tropical Africa and elsewhere (Table I).

Excessive alcoholic intake has been a feature in some of the patients, although in the majority it has been of no significance. Geevarghese, Pillai, and 
TABLE I

\begin{tabular}{|c|c|c|c|c|c|c|c|c|c|}
\hline \multirow[b]{2}{*}{ Author } & \multirow[b]{2}{*}{ Country } & \multicolumn{7}{|c|}{ CHRONIC PANCREATITIS IN TROPICAL REGIONS } & \multirow[b]{2}{*}{ Comment } \\
\hline & & $\begin{array}{l}\text { Age of } \\
\text { Patients }\end{array}$ & $\begin{array}{l}\text { Pancreatic, } \\
\text { Calcifica- } \\
\text { tion }\end{array}$ & & $\begin{array}{l}\text { Diabetes } \\
\text { Mellitus }\end{array}$ & Alcoholism & $\begin{array}{l}\text { Mal- } \\
\text { nutrition }\end{array}$ & $\begin{array}{l}\text { Biliary Tract } \\
\text { Disease }\end{array}$ & \\
\hline Sir A. Cooke (1897) & $\begin{array}{l}\text { Uganda } \\
1 \text { case }\end{array}$ & $\begin{array}{l}\text { Middle } \\
\text { aged }\end{array}$ & Absent & - & - & + & + & - & $\begin{array}{l}\text { Pancreas } \\
\text { sclerosed and } \\
\text { enlarged }\end{array}$ \\
\hline Miller (1951) & $\begin{array}{l}\text { Kenya } \\
1 \text { case }\end{array}$ & 18 years & - & - & - & - & & & $\begin{array}{l}\text { Increased } \\
\text { urinary } \\
\text { amylase }\end{array}$ \\
\hline Zuidema (1959) & $\begin{array}{l}\text { Indonesia } \\
45 \text { cases }\end{array}$ & $\begin{array}{l}75 \% \text { less } \\
\text { than } 31 \\
\text { years }\end{array}$ & 18 & $\mathbf{0}$ & 43 & None & + & - & \\
\hline Shaper (1960) & $\begin{array}{l}\text { Uganda } \\
20 \text { cases }\end{array}$ & $\begin{array}{l}\text { Average } \\
\text { age } 29 \\
\text { years }\end{array}$ & 20 & 2 & 10 & $\begin{array}{l}\text { Four } \\
\text { cases } \\
\text { possibly } \\
\text { alcoholic }\end{array}$ & 13 & Rare & \\
\hline $\begin{array}{l}\text { Geevarghese et al. } \\
\text { (1962) }\end{array}$ & $\begin{array}{l}\text { S. India } \\
100 \text { cases }\end{array}$ & $\begin{array}{l}75 \text { less } \\
\text { than } 25 \\
\text { years }\end{array}$ & 100 & - & 100 & $\begin{array}{l}94 \% \text { non- } \\
\text { alcoholic }\end{array}$ & $\begin{array}{l}\text { Not } \\
\text { significant }\end{array}$ & $\begin{array}{l}\text { Not } \\
\text { significant; } 43 \\
\text { cases proven } \\
\text { to be normal }\end{array}$ & $\begin{array}{l}\text { Four cases had } \\
\text { a history of } \\
\text { mumps. Five } \\
\text { cases had } \\
\text { hepatic cirrhosis }\end{array}$ \\
\hline $\begin{array}{l}\text { Bourgoignie et al. } \\
\quad(1962)\end{array}$ & $\begin{array}{l}\text { Congo } \\
3 \text { cases }\end{array}$ & $\begin{array}{l}12,23, \\
\text { and } 25 \\
\text { years }\end{array}$ & $\begin{array}{l}\text { All } 3 \\
\text { cases }\end{array}$ & $\begin{array}{l}\text { One had frank } \\
\text { steatorrhoea. } \\
\text { All had } \\
\text { increased } \\
\text { faecal fat }\end{array}$ & 1 & $\begin{array}{l}\text { No } \\
\text { evidence }\end{array}$ & $\begin{array}{l}\text { Severe } \\
\text { features }\end{array}$ & - & \\
\hline Merlihot (1963) & $\begin{array}{l}\text { Madagascar } \\
5 \text { cases }\end{array}$ & $\begin{array}{l}\text { Ages } \\
\text { exceeded } \\
30 \text { years }\end{array}$ & 4 & Not known & 3 & 4 & 3 & $\begin{array}{l}\text { One case with } \\
\text { obstructive } \\
\text { jaundice }\end{array}$ & \\
\hline Kinnear (1963) & $\begin{array}{l}\text { Nigeria } \\
30 \text { cases }\end{array}$ & $\begin{array}{l}67 \% \text { below } \\
20 \text { years }\end{array}$ & v 30 & $\begin{array}{l}10-20 \mathrm{~g} . \mathrm{fat} / \\
\text { day in } 10 \text { cases } \\
\text { studied }\end{array}$ & 30 & None & $\begin{array}{l}86 \% \\
\text { underweight }\end{array}$ & - & \\
\hline Joffe (1963) & $\begin{array}{l}\text { S. Africa } \\
1 \text { case }\end{array}$ & 12 years & 1 & - & 1 & - & + & 0 & \\
\hline $\begin{array}{l}\text { Ratnaike and } \\
\text { Rajasuriya (1963) }\end{array}$ & $\begin{array}{l}\text { Ceylon } \\
1 \text { case }\end{array}$ & 19 years & Present & $\begin{array}{l}10.7 \% \text { dry } \\
\text { weight }\end{array}$ & Absent & None & Severe & None & $\begin{array}{l}\text { Wt. } 41 \mathrm{~kg} . \\
\text { Fatty liver } \\
\text { Hb } 9.8 \% \\
\text { Alb. } 2.9 \mathrm{~g} . \% \\
\text { Parotid } \\
\text { enlargement, } \\
\text { features of } \\
\text { malnutrition }\end{array}$ \\
\hline $\begin{array}{l}\text { Goodall and } \\
\text { Pilbeam (1964) }\end{array}$ & $\begin{array}{l}\text { Nyasaland } \\
2 \text { cases }\end{array}$ & $\begin{array}{l}\text { Male } 40 \\
\text { Male } 50\end{array}$ & $\begin{array}{l}\text { Present } \\
\text { Absent }\end{array}$ & - & $\begin{array}{l}\text { Present } \\
\text { Present }\end{array}$ & - & $\begin{array}{l}\text { Present } \\
\text { Present }\end{array}$ & $\begin{array}{l}\text { None } \\
\text { None }\end{array}$ & \\
\hline
\end{tabular}

Pitchumoni (1963) from South India, and Kinnear (1963) in Nigeria, in particular, emphasize the major features of their patients as being malnutrition, diabetes, and pancreatic calcification presenting in young patients without any relation to alcoholism or gall bladder disease. Steatorrhoea has only been described infrequently but this may only be a result of the limited investigational facilities available in tropical countries for detecting steatorrhoea.

When considered together, these reports suggest that there may be a unique form of chronic pancreatic disease in tropical regions developing early in life, unassociated with biliary disease or alcoholism, which is manifest as diabetes mellitus, or, less frequently, as a malabsorptive state.

\section{MATERIAL}

All patients with a suspected malabsorption state were studied in the medical wards at Mulago Hospital, the teaching hospital of Makerere University College,
Kampala, Uganda, during a two-year period. The hospital has 870 beds and serves a population of about one million people living within a 30 -mile radius of Kampala, the major city of Uganda. The main tribe, the Buganda, are of Bantu stock and have the banana as a staple foodstuff, eaten after steaming, with a vegetable stew. Also large-scale immigration of other tribes has occurred in the last 30 or $\mathbf{4 0}$ years. The immigrants, who come mainly from Burundi and Ruanda, have a lower standard of living than that of the Buganda and are often malnourished (Gangora and Norris, 1958). Their staple diet consists of maize meal, cassava, and sweet potato with variable amounts of protein foodstuffs in the form of fish or meat added according to their financial means.

Twelve patients with pancreatic calcification and diabetes mellitus were attending the hospital diabetic clinic before this study was started. All of these patients were admitted to the medical wards some time during 1961 and 1963 for treatment, but they do not represent cases presenting for the first time during the two years of the survey. All other patients attended for the first time. Certain groups of patients were investigated in detail. 
DIABETIC PATIENTS All diabetic patients who attended for the first time had upper abdominal $x$-ray films to detect pancreatic calcification. All detected cases of pancreatic calcification were studied in detail. A group of 14 diabetic patients, who gave a history of abdominal pain or had features of severe malnutrition, were also investigated for latent exocrine pancreatic disease.

RECURRENT ABDOMINAL PAIN In a few instances, patients were admitted for investigation of unexplained abdominal pain. Hookworm infection and peptic ulceration were excluded by appropriate studies before commencing malabsorption investigations.

CHRONIC DIARRHOEA Cases of chronic diarrhoea of more than two weeks' duration were always fully investigated. Amoebic disease and bacillary dysentery were excluded by stool cultures and blood examination.

SEVERE MALNUTRITION Any patient who presented to the hospital with severe malnutrition without obvious cause was studied in detail. They usually presented with complaints of diffuse body swelling due to oedema, malaise, and loss of energy. Chronic illness such as pulmonary tuberculosis, hookworm disease, and the nephrotic syndrome were excluded by appropriate studies.

\section{METHODS}

GENERAL PROCEDURES Standard haematological and biochemical methods as described by Dacie and Lewis (1963), Varley (1962), and King and Wootton (1956) were used. Normal values for the clinical laboratories were similar to those reported from the University College, Ibadan, Nigeria, by Edozien (1958). Serum folate activity was assayed using L. casei (Waters and Mollin, 1961) and vitamin $\mathrm{B}_{12}$ using $L$. leishmannii (Meynell, Cooke, Cox, and Gaddie, 1957). Vitamin $B_{12}$ absorption tests were performed according to the Ellenbogen and Williams (1958) modification of the Schilling technique (1953).

SPECIAL GASTROENTEROLOGICAL PROCEDURES Stool specimens were collected for 72 hours in cans and weighed. The normal stool weight for a three-day collection did not exceed 900 g. (Banwell, Campbell, Blackman, Hutt, and Leonard, 1963).

Faecal fats were estimated by the method of Van de Kamer, Huinink, and Weijers (1949). Thirteen 72-hour collections from patients without gastrointestinal disorders were analysed. The mean daily faecal fat output was $2.53 \mathrm{~g}$. \pm S.D. $1.51 \mathrm{~g}$. The daily dietary intake of fat for patients on ward diets at Mulago Hospital is low by European and North American standards. In two dietary assessments the daily dietary fat intake was $24.2 \mathrm{~g}$. and $34 \mathrm{~g}$. respectively, and an analysis of the fat content of a pooled diet gave a value for the daily fat intake of $39.6 \mathrm{~g}$.

The diet had a high fibre and roughage content but this did not appear to increase the faecal fat output above the normal levels found for patients on a western type of diet. Holmes and Darke (1959) obtained similar values for normal faecal fat loss during balance studies carried out on normal East African adults. Walker (1949), however, has reported that although a low fat intake produced little change in fat excretion a high fibre intake in two Bantu subjects caused an increase in faecal fat output above the normal accepted range of $7 \mathrm{~g}$. per day. In order to avoid attaching undue importance to small alterations in faecal fat excretion, steatorrhoea has been defined in this study as a faecal fat output in excess of $7 \mathrm{~g}$. per day. This value represents three standard deviations from the mean faecal fat output for control Ugandan patients and is similar to the upper limit for the faecal fat of normal subjects on European or North American diets (Wollaeger, Comfort, and Osterberg, 1947; Cooke, Thomas, Mangall, and Cross, 1953). It is possible that by using $7 \mathrm{~g}$. as the upper limit of the normal range, in Uganda occasional mild cases of the malabsorption syndrome may have been overlooked. However, since this study was only concerned with well defined abnormalities of assimilation, the error had no serious clinical significance.

A small quantity of the three-day sample was examined microscopically by the technique used by Drummey, Benson, and Jones (1961).

d-Xylose excretion tests were performed according to the method of Santini and co-workers (1961) using a $5 \mathrm{~g}$. loading dose. The normal range established by Joske and Haagensen (1964) has been used (mean five-hour excretion $1.75 \mathrm{~g} . \pm 0.43 \mathrm{~g}$.) in this study.

VITAMIN A ABSORPTION TESTS The serum level of vitamin A was low in Africans in Uganda, though the content in the liver was normal (Leonard, 1964). This feature altered the usual interpretation of the results of a standard vitamin A absorption test (Leonard and Banwell, 1964). All cases of malabsorption had abnormal five-hour serum vitamin A levels ( $<30 \mu \mathrm{g} . \%)$. In this study the five-hour vitamin A level was used as confirmatory evidence rather than absolute proof of steatorrhoea.

PANCREATIC FUNCTION STUdies Serum amylase values were estimated by a Somogyi method. Secretin-pancreozymin tests were carried out according to the technique of Burton, Evans, Harper, Howat, Oleesky, Scott, and Varley (1960) in all patients. The normal range for African subjects using this test has been defined (Banwell and Campbell, 1967). Small bowel biopsies were taken with a Crosby-Kugler capsule.

NECROPSY STUDIES These were carried out on eight subjects who died while in the ward. In all instances the post-mortem examination was carried out within a few hours of death and post-mortem autolytic changes were thereby reduced to a minimum.

Standard bacteriological procedures were used for culturing stools, urine, and blood. Stools were examined by the formol ether concentration technique for ova, cysts, and parasites (Ridley and Hawgood, 1956). Rectal snips were examined for schistosome ova in some instances. In studies in hookworm anaemia, adult worms were counted after sieving and washing the stools (Blackman, Marsden, Banwell, and Craggs, 1965). 
TABLE II

MALABSORPTION SYNDROMES AT MULAGO HOSPITAL 1961-1963

Major Causative Disease
Pancreatic exocrine disease with lithias
(a) With diabetes mellitus
(b) Without diabetes mellitus
Pancreatic exocrine disease without
calcification
(a) With diabetes mellitus
(b) Without diabetes mellitus
Non-pancreatic causes
Folic acid deficiency (tropical sprue)
Gastric operation
Intestinal tuberculosis.
Strongyloidiasis
Diabetic diarrhoea
Ileocaecal disease of uncertain cause
Unidentified cases of steatorrhoea
'Pancreatic lithiasis present

Number Steatorrhoea of Cases (g./day)

$\left.\left.\begin{array}{rl}21 \\ 19 \\ 2\end{array}\right\} \begin{array}{l}8 \cdot 1-56 \cdot 3 \\ 9 \\ 3 \\ 6\end{array}\right\} \begin{aligned} & 7 \cdot 9-17 \cdot 6 \\ & \end{aligned}$

RESULTS

GENERAL FEATURES During the two-year period, 45 patients with the malabsorption syndrome were studied. Thirty cases had steatorrhoea which could be attributed, wholly or in part, to chronic pancreatic disease: 15 other patients had malabsorption due to a variety of non-pancreatic disorders.

The results are summarized in Table II.

The criteria used for diagnosis of chronic exocrine pancreatic disease were: pancreatic calcification detected by routine radiology of the upper abdomen; an abnormal response to the secretin-pancreozymin test of Burton and co-workers (1960); details of the test procedure and the results for patients with chronic pancreatic disease in Uganda have been described elsewhere (Banwell and Campbell, 1967). Biopsy or post-mortem histological evidence of chronic pancreatic disease; an abnormal glucose tolerance test.

At least one of the first three of these criteria had to be fulfilled to substantiate a diagnosis of chronic pancreatic disease.

CHARACTERISTICS OF 30 PATIENTS WITH PANCREATOGENOUS STEATORRHOEA Ages ranged from 10 to 50 years. In the group with malabsorption $57 \%$ of patients were under 30 years of age, the mean age of the group being 25.8 years for Ruanda subjects and 33.6 for Ganda patients.

There were 24 males and six females, a male to female ratio of 4:1. A similar sex distribution was found by Shaper and Shaper (1958) for general hospital admissions to Mulago Hospital. There was no difference in height between the normal group defined by Coles (1957) and the malabsorption cases but the mean weight of patients with malabsorption was approximately $20 \%$ below that of the control group.

The majority of patients were peasant farmers or cultivators, although the amount of land owned and the wages earned varied considerably. Many Ruanda were poor peasants who worked for Ganda coffee and cotton growers in similar conditions to those described by Richards (1954). The wealth of Ganda cultivators was usually greater than that of Ruanda.

SYMPTOMS The major symptoms were abdominal pain, features of diabetes mellitus, namely, polyuria, polydipsia, and increased appetite, and generalized swelling of the body with changes in the colour of hair and skin. Diarrhoea and complaints of weakness and malaise were less prominent features.

Abdominal pain Abdominal pain was a major symptom in 23 cases (76.5\%). The pain described varied from a vague diffuse abdominal discomfort of a persistent low-grade type to episodic attacks of epigastric and left upper quadrant pain which radiated through the back.

Frequently the duration of the pain had been for only three to six months, although gross pancreatic calcification detected on admission suggested that actual pancreatic disease had been present for a much longer time. Seven patients had had no abdominal pain.

Diabetic symptoms The main symptoms of diabetes were polyuria and polydipsia. These were present in 18 patients $(60 \%)$. Three patients with proven diabetes mellitus had no symptoms of the disease. One patient presented with lenticular cataracts which required surgical treatment.

Features of malnutrition This feature occurred in 14 subjects $(46.5 \%)$ who had developed nutritional changes. All patients who had noticed them described their development over the proceeding two years to two months. Generalized oedema was present in the face and trunk, as well as to a more marked degree in the thighs and legs. Ascites was uncommon (three cases); changes in the colour of the skin and hair had been noticed by eight patients. Weakness and malaise were noticed by patients who found increasing difficulty in carrying on their work. This state was aggravated by a reduced appetite and, in the severe stages, not only extreme anorexia, but frank repugnance to all foods developed.

Diarrhoea Diarrhoea was a difficult symptom to assess. Normal bowel habits of Ugandan people usually involve the passage of two to three formed, semi-solid stools per day. An increase above three bowel movements a day, or increased wateriness of the stools, was considered to be diarrhoea. Although $40 \%$, i.e., 12 cases, had these symptoms, they were seldom a positive complaint and only direct question- 
ing elicited the symptom. Rectal seepage of fat was not described. One patient with faecal incontinence had associated peripheral diabetic neuropathy.

Family history In only one pair of brothers, who had pancreatic calcification and diabetes mellitus, was there evidence of a familial relationship. One of the patients with pancreatic lithiasis and diabetes had a half sister who developed diabetes mellitus.

PHYSICAL FINDINGS The characteristic patient was thin and wasted, unless oedema was also present, when a bloated appearance masked the presence of considerable loss of subcutaneous tissue and muscle mass.

Weakness and easy fatigue were evident from the stooping gait and slow movements. In extreme cases this was shown by the patients' reluctance to leave heir beds, where they would lie curled under the tbed clothes, unwilling to move or even take food.

The other major physical features were those which arose in ectodermal structures: the hair, skin, nails, and mucous membranes.

Hair changes Hair changes were present in 23 subjects $(77 \%)$. The hair was soft in texture, with loss in elasticity and curliness. It was frequently yellowish-brown, having lost its black sheen, and the scalp showed evidence of diffuse alopecia, more marked at sites of pressure, particularly over the occipital region where there was contact with the pillow. The eyelashes, eyebrows, axillary and pubic hair were similarly though less frequently affected.

Skin and nail changes Alteration in the skin was observed in 13 cases $(43.5 \%)$. The skin was dry and rough, characterized by hyperkeratotic plaques of epidermal tissue of a polygonal shape which developed into white scales. The areas most affected were those subjected to trauma but the back, trunk, and buttocks may also be involved. The skin in all areas was dry and had lost its waxy fatty coating. Skin biopsies in two cases demonstrated atrophy of both sweat glands and sebaceous glands, with thinning of the Malpighian and granular layer associated with epidermal hyperkeratosis. In two patients with severe malnutrition the nails were soft and flexible, showing longitudinal ridging and flattening.

Mucous membrane changes These features were only encountered in nine patients $(30 \%)$ : glossitis (nine cases), angular stomatitis (two cases), and cheilosis (two cases). They improved rapidly when diabetes was controlled and a normal ward diet was instituted.

Salivary gland enlargement A conspicuous feature of practice in tropical areas is the prevalence of painless enlargement of the parotid glands and, occasionally, of the maxillary glands as well. This feature was present in 18 of the group of $\mathbf{3 0}$ patients $(60 \%)$. The parotid glands were diffusely enlarged and were in contrast with the emaciated facial appearance of the patients. In no instance were they painful. The enlargement increased in five cases during hospital admission, at a time when diabetes mellitus was being treated and an improved diet had been instituted. No evidence of xerostomia was detected. Both Zuidema (1959) and Kinnear (1963) had noted similar features in their diabetic patients with pancreatic lithiasis, although Shaper (1961) has doubted whether this feature has any particular significance since it is found so frequently in the normal population. Farago (1964) has suggested that parotid hypertrophy is due to hyperactivity and 'work hypertrophy' occasioned by the high carbohydrate intake in the diet, and there is evidence to support such a hypothesis in the parotid hypertrophy which may accompany excessive starch consumption (Merkatz, 1961).

Additional features Tuberculous infections were detected in four cases: three were diabetic. One case was found to have primary tuberculous enteritis at necropsy, in association with pancreatic lithiasis. Optic atrophy, due to methyl alcohol poisoning, occurred in one patient.

Neurological findings Evidence of peripheral neuropathy was detected in five cases. In no instance was it a primary complaint. Sensory changes were present in one patient and another had muscle wasting, associated with loss of lower limb reflexes. The remainder had, as the only evidence, loss of achilles tendon reflexes. All were diabetic patients.

There were no features, either historical or on examination, which suggested that any of the group had ever had delirium tremens, Wernicke's encephalopathy, or alcoholic neuritis.

LABORATORY INVESTIGATIONS The results are set out in Table III. Eleven patients had normal haemoglobin levels when compared with normal values obtained from an East African student population (Shaper, Kyobe, and Stansfield, 1962) and normal adult East African population (Lehmann, 1949). All values exceeded $13 \mathrm{~g}$. per $100 \mathrm{ml}$. Thirteen patients had haemoglobin values between 10 and $13 \mathrm{~g}$. per $100 \mathrm{ml}$. Two of this group had moderate to heavy hookworm loads in the stools, and four others had evidence of megaloblastic changes in the bone marrow attributed to folate deficiency. Six patients had haemoglobin concentrations of less than $10 \mathrm{~g}$. per $100 \mathrm{ml}$. on presentation. One patient (case 15) had associated tuberculous enteritis. Three had heavy hookworm loads, two had mild megaloblastic changes attributable to folic acid deficiency, and one patient had had unexplained rectal bleeding before admission. 
TABLE III

LABORATORY FINDINGS

\begin{tabular}{|c|c|c|c|c|c|c|c|c|c|c|c|}
\hline \multirow{2}{*}{$\begin{array}{l}\text { Case } \\
\text { No. }\end{array}$} & \multirow{2}{*}{$\begin{array}{l}\text { Weight } \\
\text { (kg.) }\end{array}$} & \multirow{2}{*}{$\begin{array}{l}\text { Pancreatic } \\
\text { Lithiasis }\end{array}$} & \multirow{2}{*}{\multicolumn{2}{|c|}{$\begin{array}{l}\text { Haemoglobin } \\
(\mathrm{g} . / 100 \mathrm{ml} .)\end{array}$}} & \multirow{2}{*}{$\begin{array}{l}d-X y l o s e \\
\text { Excretion } \\
\text { (g. } 15 \text { hour) }\end{array}$} & \multicolumn{2}{|c|}{ Vitamin A Absorption } & \multirow{2}{*}{$\begin{array}{l}\text { Amylase } \\
(\text { unit } \mid \\
100 \mathrm{ml} .)\end{array}$} & \multirow{2}{*}{$\begin{array}{l}\text { Fasting } \\
\text { Blood } \\
\text { Sugar } \\
\text { (mg./100 } \\
\text { ml. })\end{array}$} & \multirow{2}{*}{$\begin{array}{l}\text { Stool Wet } \\
\text { Weight } \\
\text { (g./3 day) }\end{array}$} & \multirow{2}{*}{$\begin{array}{l}\text { Faecal Fat } \\
\text { (mean 3-day } \\
\text { collection) } \\
(\mathrm{g} .124 \mathrm{hr} .)\end{array}$} \\
\hline & & & & & & $\begin{array}{l}\text { o Hours } \\
\text { ( } \mu \mathrm{g} . / 100 \\
\mathrm{ml} .)\end{array}$ & 5 Hours & & & & \\
\hline
\end{tabular}

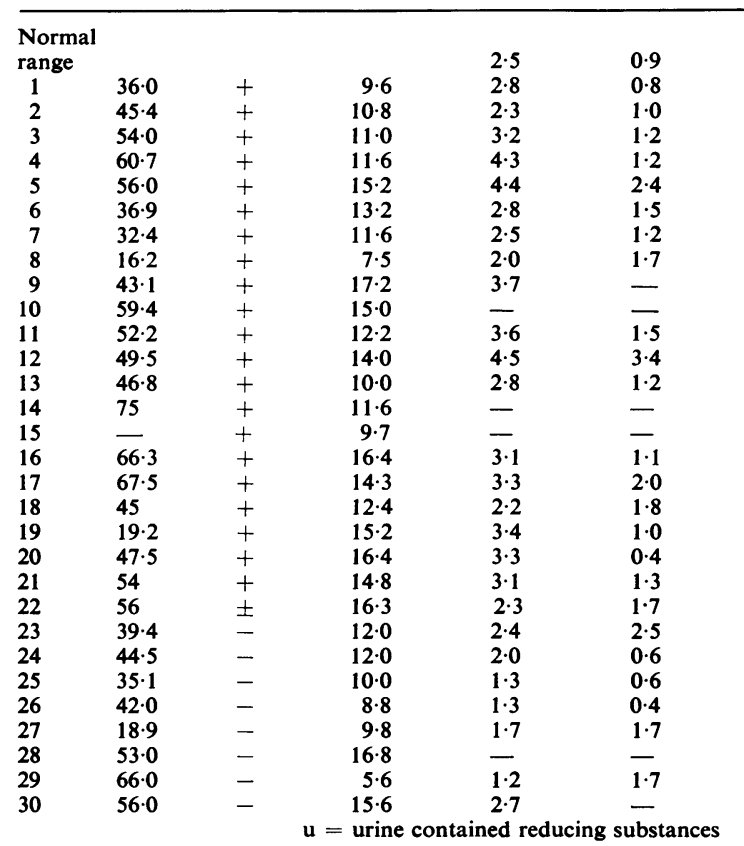

\begin{tabular}{|c|c|c|c|c|}
\hline & 30 & 200 & 80 & 900 \\
\hline 0 & 63.9 & 260 & 600 & 1,928 \\
\hline - & - & 92 & 220 & 685 \\
\hline - & - & 150 & 400 & 914 \\
\hline- & - & 182 & $97^{1}$ & 1,988 \\
\hline- & - & 122 & 206 & 790 \\
\hline- & - & 104 & $110^{1}$ & 1,357 \\
\hline $8 \cdot 1$ & $38 \cdot 0$ & 135 & 400 & 1,088 \\
\hline $6 \cdot 3$ & 8.7 & 151 & 58 & 356 \\
\hline - & - & 187 & 280 & 1,598 \\
\hline $2 \cdot 1$ & $2 \cdot 5$ & 133 & $55^{1}$ & 1,104 \\
\hline 0 & 0 & 150 & 200 & 449 \\
\hline - & - & 94 & 350 & 1,697 \\
\hline - & - & 80 & 345 & 1,045 \\
\hline- & - & 95 & 175 & 1,413 \\
\hline- & - & - & $-\mathbf{u}$ & 1,400 \\
\hline $2 \cdot 5$ & 2.5 & 143 & 140 & 627 \\
\hline 一 & - & - & 300 & 500 \\
\hline - & - & 116 & 250 & 226 \\
\hline 0 & 0 & 250 & 100 & 629 \\
\hline- & - & 138 & $100^{1}$ & 896 \\
\hline- & - & 200 & $-\mathbf{u}$ & 1,843 \\
\hline $6 \cdot 3$ & $7 \cdot 5$ & 87 & 100 & 1,35 \\
\hline $2 \cdot 1$ & $2 \cdot 5$ & 108 & 170 & 1,391 \\
\hline 0 & 0 & 308 & $98^{1}$ & 1,019 \\
\hline $2 \cdot 5$ & $2 \cdot 6$ & 102 & 80 & 1,364 \\
\hline - & - & - & - & - \\
\hline 0 & 0 & 250 & - & 25 \\
\hline- & - & 1,090 & 80 & 67 \\
\hline- & - & 185 & 86 & 830 \\
\hline $17 \cdot 4$ & $35 \cdot 1$ & 67 & 350 & 1,59 \\
\hline
\end{tabular}

Serum proteins The serum albumin level was significantly reduced in 10 patients, i.e., below $2.5 \mathrm{~g}$. per $100 \mathrm{ml}$. The patients with hypoproteinaemia always had physical features of malnutrition as described previously.

Serum amylase One patient presented with acute on chronic pancreatitis and a serum amylase value of 1,090 units per $100 \mathrm{ml}$. Four other patients all had raised amylase values during times when they were experiencing pain of pancreatic type.

Serum cholesterol Seven values for serum cholesterol were significantly lower than the mean for adult males around Kampala (Shaper and Jones, 1959). All these subjects were malnourished.

Aminoaciduria Urine samples from 20 patients were studied by two-directional paper chromatography. Three patients showed a generalized aminoaciduria of a type similar to that seen in kwashiorkor.

Five others demonstrated increased amounts of indican and four Ganda patients had indolyl acryly glycine present in increased quantities. This substance has been shown to occur in the urine of normal Uganda people on a matoke or banana diet (Banwell and Crawford, 1963; Crawford, 1964). No patient was found to have a cysteine-lysine pattern similar to that described in hereditary forms of pancreatitis (Gross, Ulrich, and Maher, 1962).

Carbohydrate metabolism Seventeen patients in the grcup had frank diabetes with hyperglycaemia. Thirteen patients had normal random blood sugar values and no evidence of lycosuria on presentation to the hospital. Five of these had an abnormal glucose tolerance test. Three patients developed diabetes from two to eight years after the pancreatic disease had been first diagnosed. Six of the patients without diabetes had pancreatic calcification.

No abnormality was detected in either the serum calcium or lipid levels of these patients. Sweat tests were normal on all patients.

Stool weight The weight of the three-day stool collections ranged from $226 \mathrm{~g}$. to $1,988 \mathrm{~g}$. Stool weights of over $900 \mathrm{~g}$. for three-day collections were common in association with pancreatic exocrine disease. Steatorrhoea was detected in stool specimens of normal weight, but was almost invariably present when the three-day stool weight exceeded $900 \mathrm{~g}$.

The weight of three-day stool specimens, inspection by the naked eye, and microscopic examination 


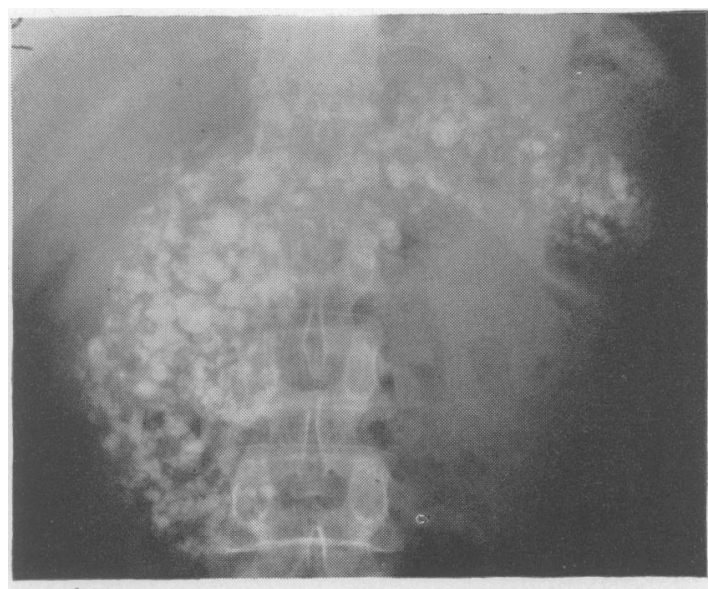

FIG. 1 a.

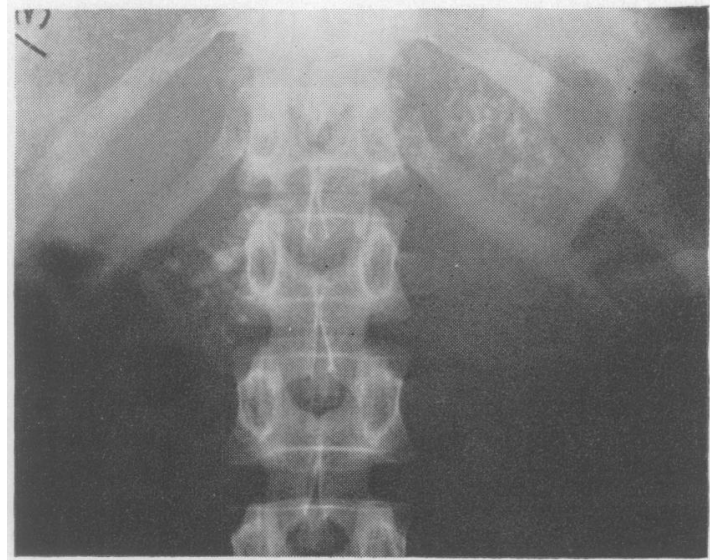

FIG. $1 \mathrm{~b}$.

FIG. $1 \mathrm{a}$ and $1 \mathrm{~b}$. Severe and moderate pancreatic calcification.

with Sudan III gave a useful preliminary indication of steatorrhoea in 14 of 30 patients before faecal fat analysis was undertaken.

$d$-Xylose excretion test Five patients had values below the normal range, i.e., below $0.9 \mathrm{~g}$. in five hours. Four of the five patients had jejunal biopsies which, on histological examination, conformed to the classical description of partial villous atrophy or subtotal villous atrophy.

RADIOLOGY Radiological studies were made of the pancreas, the small intestine, and the biliary tract.

Pancreatic calcification Twenty-one patients had evidence of definite pancreatic lithiasis (Fig. 1aand b). In 20 cases there was diffuse intraductal calcification involving at least two regions of the gland, and, in 19 instances, all three areas. The distribution was not uniform; the greatest involvement was usually in the head of the gland but in three the tail was heavily involved. The wide distribution in some cases suggested that the gland had become enlarged and swollen by the pathological changes which accompanied lithiasis formation. Two patients, who subsequently came to necropsy, were found to have small areas of calcification in ductal debris, although abdominal radiographs did not show any opacities.

The calculi varied in size and shape. In some instances there was a fine diffuse pattern of calcification, in others the calculi were of many different sizes. Calculi were seen to increase in size in serial radiographs in three cases. There was no correlation between pancreatic calcification and the degree of steatorrhoea. Two patients who had obstruction to the common bile duct had calcification within the head of the gland. Pancreatic pseudocyst formation was not detected.

Small intestine Radiological examination of the small bowel was carried out in 25 of the 30 patients. The criteria used for assessment of films were those described by Laws, Booth, Shawdon, and Stewart (1963).

Five patients had bowel loops of $30 \mathrm{~mm}$. or more in diameter. Mucosal folds were thickened in all these patients. Dilatation never exceeded $35 \mathrm{~mm}$. and the abnormalities were, therefore, only classified as moderate. There was no correlation between the degree of dilatation and the degree of steatorrhoea. The severe dilatation and thickening of the valvulae conniventes as seen in adult coeliac disease and tropical sprue (Paterson, David, and Baker, 1965) were never observed in patients with malabsorption due to chronic pancreatic disease.

Biliary tract Oral cholecystography or intravenous cholangiography was carried out on 24 of the patients. In all instances the gall bladder was visualized and no evidence of cholelithiasis found.

In two cases intravenous cholangiography demonstrated partial obstruction of the common bile duct within the head of the pancreas.

Parasitology Stool examinations were carried out on all but two of the patients. Five had moderate to heavy hookworm loads with associated occult blood on examination of the stools. Removal of the hookworm by vermifuge had no appreciable effect on the steatorrhoea in these cases (Banwell, Marsden, Blackman, Leonard, and Hutt, 1967). One case had E. histolytica cysts in the stools in the absence of free forms. Occult blood tests were negative and no evidence of amoebic colitis was discovered at necropsy some six months later. Two patients had ascaris ova in moderate numbers. Taenia saginata was found in three cases. No Giardia lamblia were identified in any of the patients. 


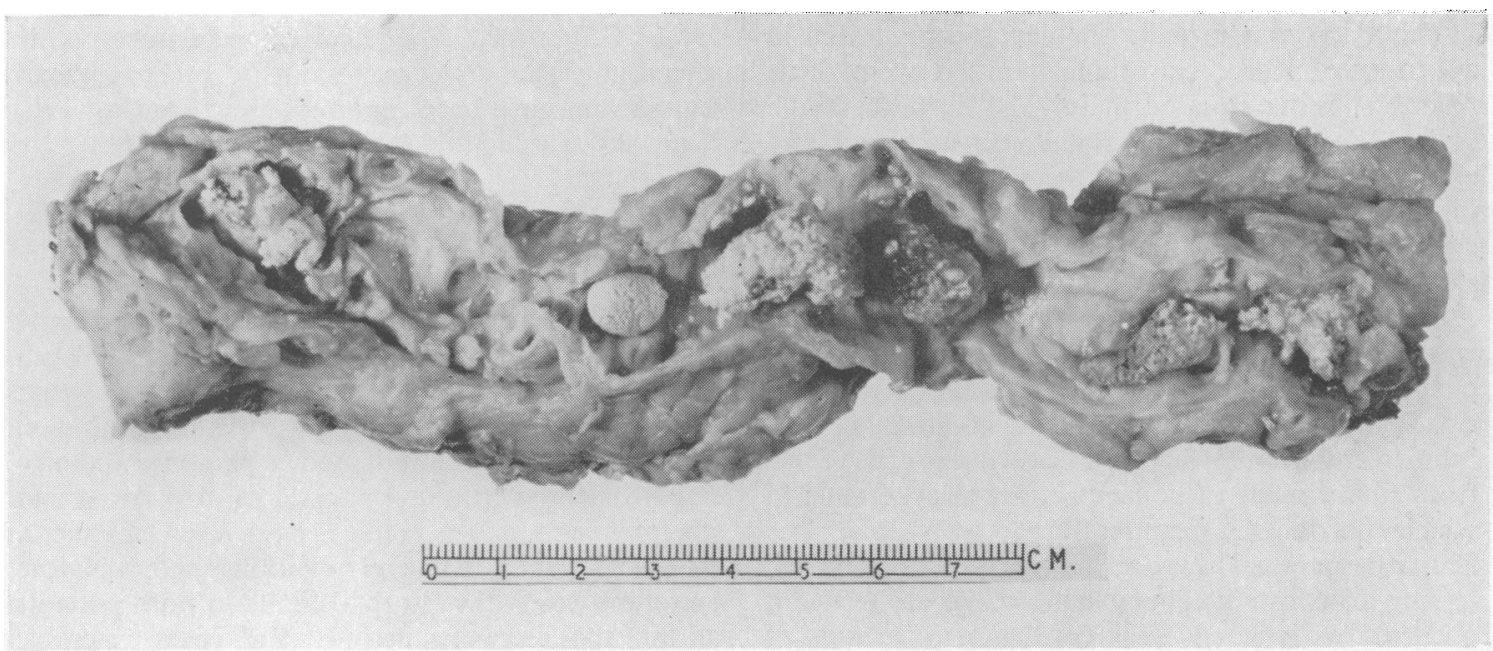

FIG. $2 \mathrm{a}$.

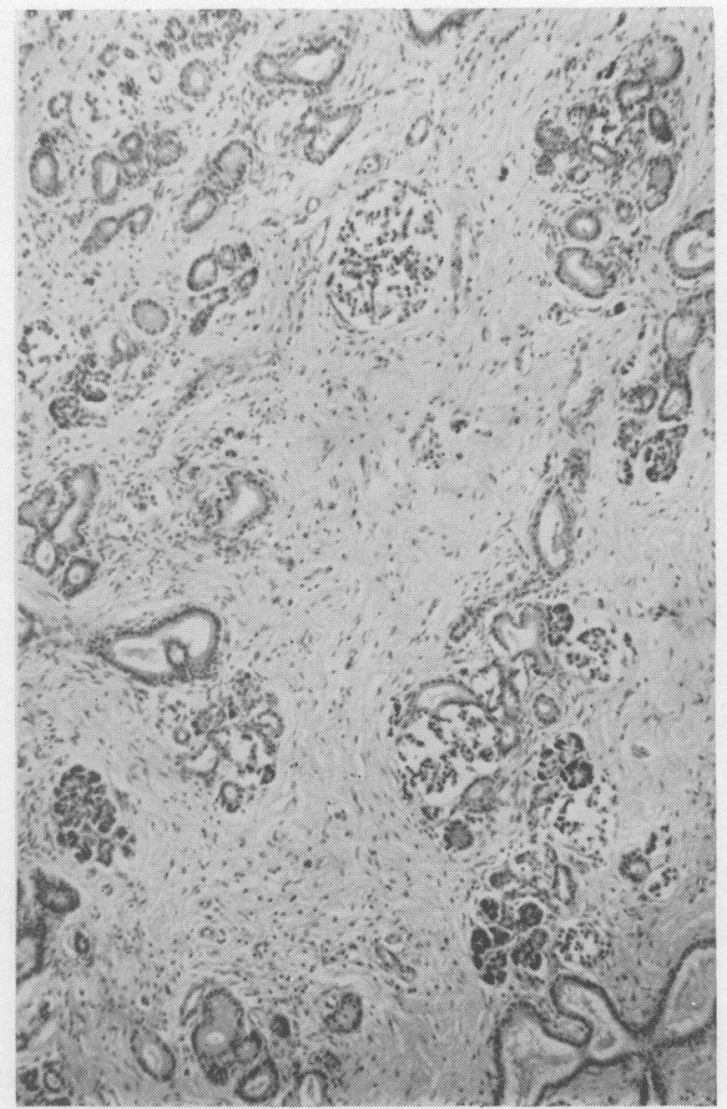

FIG. $2 b$.

FIG. 2. Chronic pancreatic disease: (a) gross appearance of the pancreas, and (b) histological features.
EXOCRINE PANCREATIC DISEASE WITHOUT STEATORRHOEA Twelve additional patients who had pancreatic exocrine disease without steatorrhoea were detected. Seven had had faecal fat determinations which were within the normal range and five had no information available concerning steatorrhoea. The diagnosis of pancreatic disease was made on the basis of pancreatic calcification (five patients), operation or necropsy findings (six patients), and an abnormal response to the secretin-pancreozymin test (five cases). Only three patients were under 30 years of age $(25 \%)$ but the sex and tribal distribution was similar to patients with pancreatogenous steatorrhoea. Four patients were more than $20 \%$ below the mean weight for their size. Five had had no significant alcoholic intake, while five probably drank excessive amounts of alcoholic spirits. Eight patients presented with symptoms of abdominal pain and one with diarrhoea. Diabetes mellitus was present in five, with an abnormal response to an oral glucose tolerance test in one other. Two patients had hepatic cirrhosis accompanied by jaundice. Four patients had serum albumin levels of $2.5 \mathrm{~g}$. per $100 \mathrm{ml}$. or less. Vitamin A absorption tests were normal in the six patients who were studied and d-xylose excretion was normal in four patients. Jejunal biopsy from six patients showed only mild abnormalities.

POST-MORTEM AND BIOPSY MATERIAL This was pancreas, liver, and small intestine.

Pancreas Necropsy material was available for study on eight patients, four with malabsorption and four without. Four operative pancreatic biopsies were also available. 
The gland was usually nodular and indurated in appearance. Hard, calcareous nodules were often palpable, being situated mainly in the head of the gland. Fat necrosis was present in three cases and extensive fatty infiltration of the gland in two others, in one of which no definite pancreatic acinar tissue could be identified. The gland was described as being smaller than normalin twoinstances(Figures 2a and b).

The most striking histological feature in all cases was extensive loss of acinar tissue and its replacement by fibrous tissue. The fibrous tissue was predominantly interlobular but not uncommonly intralobular and even intracinar in distribution; it varied from fine threads of collagen to extensive bands in which fibroblastic proliferation was visible. The acinar tissue was always atrophied and disorganized, having no constant lobular pattern. Where visible it occurred as isolated areas consisting of groups of acini or irregular fragmented zymogen cells separated by fibrous tissue. The cells were distorted and zymogen granules rarely seen. Islet tissue was often atrophied but no systematic attempt was made to study this feature.

The main pancreatic ducts and ductules were frequently dilated. Intraluminal laminated mucus was seen in four cases. In two instances calcification of this material had commenced. Squamous metaplasia of the duct epithelium was not seen. Bundles of nerve fibres were often to be found enmeshed in dense fibrous tissue. Lymphocytes and plasma cells infiltrated the fibrous tissue and occasionally nerve fibres. Haemosiderin deposits were found within acinar and fibrous tissue in one case.

Liver The most striking pathological changes in the liver were seen in eight patients where variable fatty infiltration of parencymal cells was accompanied by haemosiderin deposition within hepatic and sinusoidal cells. All the patients were severely malnourished and had skin and hair features of protein calorie malnutrition. The fatty infiltration was mild in one, moderate in two, and severe in five patients, and was found mainly in cells at the periphery of the lobule. Excessive iron deposition was seen in five of the patients with excess parenchymatous fat and in two with normal liver cells; two of those with haemosiderosis had diabetes. Iron deposition in the hepatic cells was also maximal in the periportal region. In two instances Mallory bodies were present. Multiple focal necroses were to be found in the severely involved liver tissue. Another patient showed progressive changes on several liver biopsy specimens to a frank cirrhosis with early pseudolobule formation and one had frank portal cirrhosis without fatty change. Biliary stasis was seen in a patient with bile duct obstruction arising within the head of the calcified pancreas.
Small Intestine The changes were non-specific resembling the changes found in other tropical regions and have been reported elsewhere (Banwell, Hutt, and Tunnicliffe, 1964).

NON-PANCREATIC CAUSES FOR STEATORRHOEA Sixteen patients had steatorrhoea without pancreatic disease.

Tropical sprue Severe megaloblastic anaemia, glossitis, and steatorrhoea characterized both patients included under this diagnostic category. Both were prisoners living on an abnormal diet. Folic acid produced a reticulocyte response and also caused haemoglobin levels to return to normal and steatorrhoea was observed to improve on treatment. Neither patient was severely malnourished. $d$-Xylose excretion was within normal limits in both patients during the recovery period. The cases resemble closely those described by Harries (1964) from Kenya, and represent a condition similar to that seen in both endemic and epidemic proportions in Asia. The jejunal biopsy changes were mild compared with those usually encountered in adult coeliac disease. ${ }^{1}$

Secondary to gastric operations One patient developed steatorrhoea following a Polya type partial gastrectomy.

Stomal ulceration was present with a gastrocolic fistula in another patient.

Intestinal tuberculosis There were two patients with intestinal tuberculosis. One represented the acute primary ulcerative variety of the disease. Pancreatic calcification was also present in this patient. The other was an example of tuberculous peritonitis in association with pulmonary tuberculous disease.

Strongyloidiasis The malabsorption syndrome in one case was attributed to generalized infection of both the small and large intestine with larval and adult forms of Strongyloides stercoralis. Although diabetes mellitus was the presenting manifestation, exocrine pancreatic structure and function were essentially normal when assessed at post-mortem examination and during a secretin-pancreozymin test. Strongyloidiasis has been recognized recently as a cause for steatorrhoea in Jamaica (Milner, Irvine, Bartin, Bras, and Richards, 1965).

Diabetic diarrhoea One case was classified as a case of diabetic diarrhoea. The presence of marked features of diabetic peripheral neuropathy and nocturnal incontinence favoured the diagnosis (Malins and French, 1957).

One patient had an ulcerating ileo-caecal disease

${ }^{1}$ Adult coeliac disease, responsive to restriction of gluten, has not been recognized amongst tropical people. With the introduction of wheat cultivation to certain of the western regions of Uganda (McMasters, 1962) it will be interesting to observe whether the disease comes to be recognized among indigenous African people. 
of unknown origin and eight other patients had steatorrhoea in whom the exact diagnosis was uncertain due to inadequate diagnostic investigations.

\section{DISCUSSION}

This study has demonstrated that malabsorption syndromes are present in patients in Uganda, East Africa. The overall incidence would seem to be much higher than had previously been expected, the syndrome accounting for approximately 20 annual admissions, a frequency intermediate between that for carcinoma of the liver and amoebic dysentery at this hospital. The total incidence was more difficult to measure accurately. Differences in medical facilities and access to biochemical investigations makes comparison between African and European groups unreliable. The same reservations apply to comparisons with South Africa, where hospital medical care has been in advance of that in other parts of Africa (Hailey, 1957). However, fewer cases were recognized in Kampala, Uganda, than in Capetown, South Africa, during a similar two-year period (Bank, Marks, Moshal, and Timme, 1964) and, moreover steatorrhoea was probably of less clinical importance in Uganda than in either Europe or India owing to the almost total absence of adult coeliac disease and tropical sprue. Chronic pancreatic disease was found to be the major cause for the malabsorption syndrome in over $65 \%$ of cases in Uganda, which is a much higher incidence of exocrine pancreatic disease than described in other published series of malabsorption cases. Badenoch (1960) reviewed 163 patients with the malabsorption syndrome from Oxford, England. Only eight cases of pancreatic disease were present, three of which were carcinomata of the pancreas. Bank, Marks, Moshal, and Timme (1964) described a three-year experience of 115 patients from Capetown, South Africa (only $10 \%$ of the group were of Bantu origin); there were 34 cases of pancreatic disease, of which 25 were attributed to chronic alcoholism.

Howard and Jordan (1960) recognize that chronic pancreatitis with pancreatic lithiasis is almost invariably due to chronic alcoholism and the overall incidence of chronic pancreatitis in European countries is also probably closely related to the incidence of alcoholism (Perrier, 1964). Alcoholic drinks, both beers and spirits, which are locally distilled, are consumed in Uganda. It is estimated that $90 \%$ of the adult population drink, although there is no accurate information about the quantities of alcoholic drinks that are consumed (Uganda Spirituous Liquor Commission Report, 1963). An assessment of the alcoholic consumption of our patients with pancreatic exocrine disease and malabsorption showed that $60 \%$ had drunk alcoholic drinks in normal or excessive quantities. Shaper (1964), who conducted a survey which included a number of the same patients, estimated that $56 \%$ of a group of 30 patients with pancreatic lithiasis had an excessive alcoholic consumption. Thus, chronic alcoholism may have been aetiologically related to pancreatic lithiasis in Uganda to some extent but it could not have contributed to the $40 \%$ of patients who never drank alcoholic drinks. Moreover, the natural history of the disease differed considerably from alcoholic pancreatitis as described from the U.S.A. and Europe. Fifty-seven percent of the total group in Kampala were under 30 years of age and of those without any history of alcoholic consumption all, except two, were under 30 years of age. Abdominal pain was rarely as severe as has been described in patients with alcoholic pancreatitis from North America and South Africa. Severe recurrent episodes were rarely seen and $23.5 \%$ of the group gave no history of abdominal pain whatsoever.

Bank, Marks, Moshal, Efron, and Silber (1963), from South Africa, had 82 of their 116 cases of alcoholic pancreatitis admitted to the hospital at some time during the course of the disease as acute abdominal emergencies, whereas only two cases of acute pancreatitis were admitted to Mulago Hospital during the two-year period of this study.

Complications associated with pancreatic calcification in this series also differ from those reported by Owens and Howard (1958). Diabetes mellitus and steatorrhoea were almost invariably present in the Uganda group, indicating an advanced stage of the disease, whereas approximately only one third of the North American patients had these features. However, hepatic cirrhosis, peptic ulcer, and gastrointestinal bleeding were much rarer in Uganda than in either the North American or South African series. These various features suggest that the disease, as found in Uganda, may be different from alcoholic pancreatitis in North America and South Africa, presenting at a much later stage with diabetes and steatorrhoea without preceeding recurrent abdominal pain (Table IV).

Biliary tract disease has a recognized association with acute pancreatitis and less frequently with chronic pancreatitis in Europe and North America but cholecystitis and cholelithiasis were both extremely rare in patients at Mulago Hospital (Shaper and Patel, 1964) and at a post-mortem examination (Owor, 1964). Biliary disease was not a cause of chronic pancreatitis in any patient of this group. Hyperparathyroidism (Cope, Culver, Mixter, and Nardi, 1957), hyperlipaemia (Klatskin and Gordon, 1962), fibrocystic disease (Hendrix and Good, 1956), 
or hereditary causes (Gross, Ulrich, and Maher, 1962) were not present in any of our cases. The other causes which have been described as occasionally related to chronic pancreatitis, such as trauma (Culotta, Howard, and Jordan, 1956), ascaris infestation (Duncan, 1948), and mumps (McGuiness and Gall, 1944), were also unimportant as aetiological factors in Uganda; neither did it seem probable that congenital hypoplasia (Bodian, Sheldon, and Lightwood, 1964) or infantile pancreatitis (Stein, 1963; Shaper and Burkitt, 1962) were, if ever, more than rare causes of pancreatic exocrine failure.

Dietary and environmental factors appeared to be of more importance in the genesis of the disease. Protein-calorie malnutrition is the commonest nutritional disorder of tropical children (Trowell and Jelliffe, 1958; Scrimshaw and Behar, 1961). Morphological changes have been described in the pancreas in kwashiorkor (Normet, 1926; Bras, Waterlow, and DePass, 1957; Davies, 1948) and a reduction in the duodenal enzyme concentration is common in this condition (Magolhaes, Carvalho, Schmidt, and Pinto, 1947; Thompson and Trowell, 1952; Gomez, Galvan, Cravioto, and Frank, 1954). However, no direct progression from infant protein calorie malnutrition to adult pancreatic insufficiency has yet been demonstrated. Veghelyi (1950), Thompson and Trowell (1952), and Gomez, Galvan, Cravioto, and Frank (1954) demonstrated that duodenal enzyme activity returned to normal with refeeding of malnourished children. The majority of pancreatic glands probably recover to a normal functional state after kwashiorkor. This fact would agree with the histological evidence at necropsy of normal acinar structure in most adult pancreatic glands in Uganda (Hutt and Connor, 1964). Zuidema (1959) first suggested that malnutrition was the cause of the adult pancreatic lesion in the group of 45 patients he studied. Severe malnutrition was, indeed, their most striking clinical feature, but Geevargheese, Pillai, and Pitchumoni (1963) found little evidence of malnutrition in the similar type of pancreatic lithiasis from South India. The malnutrition observed in adult patients with pancreatic lithiasis in Uganda and Nigeria was not an invariable feature and may have resulted from the malabsorption process instead of being an underlying cause of pancreatic disease.

Only a minority of the kwashiorkor cases of Bras, Waterlow, and DePass (1957) and Trowell, Davies, and Dean (1954) developed irreversible pancreatic fibrosis and atrophy: recovery of cellular structure was already visible in many glands of cases which had received an improved diet before death. Regeneration of acinar tissue is known to occur in the experimental animal and probably too in man (Tiscornia and Dreiling, 1966) after duct ligation and injury. Nevertheless, Trowell and Muwazi (1945) and Trowell, Davies, and Dean (1954) have evidence from necropsy studies on malnourished immigrant Ruanda labourers which favours a nutritional cause for at least some adult cases. The duration and type of dietary deficiency may be the important factor which control whether irreversible damage develops or not, as they do in the genesis of hepatic cirrhosis from fatty infiltration (Leevy, 1962). These long-term influences of infant protein-calorie malnutrition on pancreatic function might be studied by pancreatic intubation tests performed at the time of the initial illness and in the years after recovery. If severe cases were studied in this manner, the relationship of protein-calorie insufficiency to the pancreatic disease of adult life might be defined.

The evidence, therefore, suggests that an additional influence of a toxic or infective nature may be required to produce chronic pancreatic cellular destruction. Nutritional damage to the pancreas may depend not only on protein-calorie malnutrition but as much on the diet containing natural toxic chemical substances. Natural hepatotoxic agents have been identified already (Schoental, 1963; Davidson, 1963). Moreover, Schoental and Magee (1957) demonstrated that the effects of toxic pyrrolizidine alkaloids were increased by a low protein diet. It seems probable that toxic plant substances initiate other disease in primarily pastoral communities (Montgomery, 1965) and plants and herbs are known to be used throughout Africa for their medicinal properties (Watt and Breyer-Brandwijk, 1962). Careful dietary surveys in regions where pancreatic lithiasis has been described may be a means of detecting some of these noxious agents. In particular, it would be most important to attempt to search for causative agents in children whose susceptibility to toxic agents is enhanced.

Bacterial (Schweinburg, Jacob, Persky, and Fine, 1953) and viral (Blumenthal and Probstein, 1959) infections may also cause damage to the pancreas. Acute pancreatic necrosis has been described in animals (Wood, Snieszko, and Yasutake, 1955) and man (Veghelyi, 1950) after Cocksackie infections, although chronic lesions have not been recorded. Serological studies in early life could be helpful in defining such infective factors and their prevalence in patients with pancreatic disease.

The interaction of both dietary and toxic factors on the liver has already been referred to in the work of Schoental and Magee (1957) but has been studied only occasionally for the pancreas. Veghelyi and Kemanyi (1962) recently reported that the combined effect of a deficient diet and dinitrophenol on the pancreas was greater than the influence of either factor alone. Similar combined influences might be 
of importance in the genesis of the human form of pancreatic disease found in tropical regions.

Non-pancreatic causes for steatorrhoea accounted for only $35 \%$ of all the detected cases of malabsorption. A variety of miscellaneous conditions, including tropical sprue and steatorrhoea after gastric operations, accounted for this but such non-pancreatic causes of steatorrhoea appear to be uncommon in Uganda at the present time. Tropical sprue was found on only two occasions and hookworm infection was neither a direct cause of steatorrhoea nor an aggravating factor in persistent malabsorption in this community (Banwell et al., 1967).

\section{SUMMARY}

An intensive study of the malabsorption syndrome was carried out in Uganda, East Africa, during a two-year period. Forty-five patients were discovered to have the syndrome. Thirty of these had steatorrhoea which could be attributed, wholly or in part, to chronic exocrine pancreatic disease. Fifteen other patients had malabsorption due to a variety of nonpancreatic disorders.

Malabsorption syndromes represented a greater clinical problem than had previously been recognized. The character of the syndrome differed from that described from other tropical areas and the temperate regions of the world.

The disease was common in the young $(57 \%$ under 30 years of age), and more closely resembled the condition of pancreatic lithiasis described from other tropical regions than chronic pancreatitis in which alcohol was an aetiological factor. The possible causes for the syndrome have been discussed. Biliary tract disease, hyperparathyroidism, fibrocystic disease, ascaris infestation, hereditary pancreatitis, mumps, and trauma were found to be an unimportant cause of pancreatic disease in Uganda.

The virtual absence of tropical sprue from this region of Africa was confirmed. Non-pancreatic causes of steatorrhoea were found to have little clinical significance in the community at the present time.

We are grateful to Professor J. A. Tulloch for constant help and encouragement and to Professor A. G. Shaper whose work on pancreatic lithiasis and diabetes mellitus is particularly acknowledged.

One of us (J.G.B.) received grants from the East African Medical Research Council and Sanderson Wells Bequest, Middlesex Hospital, London.

We are also grateful to D. E. V. Morton of Boots Pure Drug Co., Nottingham, England, for generous supplies of secretin and pancreozymin to carry out the pancreatic function tests: to Roche Products Limited, London for supplies of vitamin A, and the Viobin Corporation, Illinois, U.S.A. for Viokase.

\section{REFERENCES}

Badenoch, J. (1960). Steatorrhoea in the adult. Brit. med. J., 2, 879-887, 963-974.

Bank, S., Marks, I. N., Moshal, M. G., Efron, G., and Silber, R. (1963). The pancreatic-function test: method and normal values. S. Afr. med. J., 37, 1061-1066.

$\longrightarrow, \frac{1}{-}$, and Timme, A. (1964). Peroral intestinal biopsy. Ibid., 38, 451-458.

Banwell, J. G., Campbell, J., Blackman, V., Hutt, M. V., and Leonard, P. (1963). Studies of intestinal function in Ugandan diabetic patients. E. Afr. med. J., 40, 277-287.

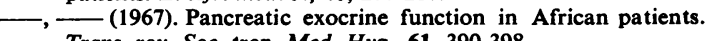
Trans. roy. Soc. trop. Med. Hyg., 61, 390-398.

- and Crawford, M. A. (1963). The identification and occurrence of indolylacrylglycine, an unexpected metabolite of tryptophan, in the urine of East Africans. Biochem J., 89, 69-70P.

-, Hutt, M. S. R. and Tunnicliffe, R. (1964). Observations on jejunal biopsy in Ugandan Africans. E. Afr. med. J., 41, 46-54.

- Marsden, P. D., Blackman, V., Leonard, P. J., and Hutt, M. S. R. (1967). Hookworm infection and intestinal absorption amongst Africans in Uganda. Amer. J. trop. Med. Hyg., to be published.

Begg, C. (1912). Sprue: Its Diagnosis and Treatment. Wright, Bristol.

Blackman, V., Marsden, P. D., Banwell, J., and Hall Craggs, M. (1965). Albumin metabolism in hookworm anaemias. Trans. roy. Soc. trop. Med. Hyg., 59, 472-482.

Blumenthal, H. T., and Probstein, J. G. (1959). Pancreatitis: A Clinical-Pathologic Correlation. Thomas, Springfield, Ill.

Bodian, M., Sheldon, W., and Lightwood, R. (1964). Congenital hypoplasia of the exocrine pancreas. Acta. paediat. (Uppsala), $53,282-293$.

Bourgoignie, J., Sonnet, J., and Dechef, G. (1962). Etude clinique du diabète sucré du Bantou de la région de Léopoldville. Ann. Soc. belg. Med. trop., 42, 261-294.

Bras, G., Waterlow, J. C., and DePass, E. (1957). Further observations on the liver, pancreas and kidney in malnourished infants and children: the relation of certain histopathological changes in the pancreas and those in liver and kidney. $W$. Indian med. J., 6, 33-42.

Burton, P., Evans, D. G., Harper, A. A., Howat, H. T., Oleesky, S., Scott, J. E., and Varley, H. (1960). A test of pancreatic function in man based on the analysis of duodenal contents after administration of secretin and pancreozymin. Gut, 1, 111-124.

Coles, R. M. (1957). The relation of height and body weight of Uganda African patients. E. Afr. med. J., 34, 619-626.

Cook, Sir A. (1897). Case records of Mulago Hospital. Kampala, Uganda.

Cooke, W. T., Thomas, G., Mangall, D., and Cross, H. (1953). Observations on the faecal excretion of total solids, nitrogen, sodium, potassium, water and fat in the steatorrhoea syndrome. Clin. Sci., 12, 223-234.

Cope, O., Culver, P. J., Mixter, C. G., Jr., and Nardi, G. L. (1957). Pancreatitis, a diagnostic clue to hyperparathyroidism. Ann. Surg., 145, 857-863.

Crawford, M. A. (1964). Degradation of amino-acids in the large gut of East Africans and its possible significance. E. Afr. med.J., 41, 228-238.

Culotta, R. J., Howard, J. M., and Jordan, G. L. (1956). Traumatic injuries of the pancreas. Surgery, 40, 320-327.

Dacie, J. V., and Lewis, S. M. (1963). Practical Haematology, 3rd ed. Churchill, London.

Davidson, C. S. (1963). Plants and fungi as etiologic agents of cirrhosis. New Engl. J. Med., 268, 1072-1073.

Drummey, G. D., Benson, J. A., Jr., and Jones, C. M. (1961). Microscopical examination of the stool for steatorrhea. Ibid., 264, 85-87.

Duncan, N. A. (1948). Pancreatitis due to ascariasis. Brit. med. J., $1,905$.

Edozien, J. C. (1958). Biochemical 'normals' in Nigerians: (i) Blood. W. Afr. med. J., 7, 121-128.

Ellenbogen, L., and Williams, W. L. (1958). Quantitative assay of intrinsic factor activity by urinary excretion of radioactive vitamin B 12. Blood, 13, 582-588.

Farago, C. (1964). Bilateral parotid gland enlargement in a tropical country, the territory of Papua and New Guinea. Med. J. Aust., 2, 218-221.

Gangora, J., and Norris, T. (1958). Summary. Fifth Report of W.H.O. Nutrition Team, Uganda. Technical Report Series No. 149, Geneva. 
Geevarghese, P. J., Pillai, V. K., and Pitchumoni, O. S. (1963). The aetiopathogenesis of chronic relapsing pancreatitis. Proc. 2 nd Wld Congr. Gastroent., Munich, 1962, IV, 159-Feibig.

Gelfand, M. (1947). Sprue and coeliac disease in Tropical Africa. Trans. roy. Soc. trop. Med. Hyg., 41, 109-118.

- (1964). A possible variety of malabsorption syndrome in the European of Rhodesia. Cent. Afr. J. Med., 10, 372-375.

Gómez, F., Gálvan, R. R., Cravioto, J., and Frenk, S. (1954). Studies on the undernourished child, XI. Enzymatic activity of the duodenal contents in children affected with third degree malnutrition. (Spanish, with English translation.) Pediatrics, $13,544-552$.

Goodall, J. W., and Pilbeam, S. T. (1964). Diabetes in Nysaland (Malawi). Trans. roy. Soc. trop. Med. Hyg., 58, 575-578.

Gross, J. B., Ulrich, J. A., and Maher, F. T. (1962). Further observations on the hereditary form of pancreatitis. In Ciba Foundation Symposium on The Exocrine Pancreas, edited by A. V. S. de Reuck, and M. P. Cameron. pp. 278-309. Churchill, London.

Hailey, W. M., Lord (1957). An African Survey. (Revised 1956). Oxford University Press, London.

Harries, J. R. (1964). Tropical sprue in the African. E. Afr. med. J., 41, $180-187$.

Hendrix, R. C., and Good, D. M. (1956). Fibrocystic disease of the pancreas after childhood: case report with necropsy at 17 years. Ann. intern. Med., 44, 166-173.

Holmes, E. G., and Darke, S. J. (1959). Malnutrition in African adults. 4. Intestinal absorption. Brit. J. Nutr., 13, 266-277.

Howard, J. M., and Jordan, G. L. (1960). Surgical diseases of the Pancreas. Lippincott, Philadelphia.

Hutt, M. S. R., and Connor, D. (1963). Personal communication.

Joffe, N. (1963). Pancreatic calcification in chilhood associated with protein malnutrition. Brit. J. Radiol., 36, 758-761.

van de Kamer, J. H., ten Bokkel Huinink, H., and Weyers, H. A. (1949). Rapid method for the determination of fat in feces. J. biol. Chem., 177, 347-355.

King, E. J., and Wootton, I. D. P. (1956). Micro-Analysis in Medical Biochemistry, 3rd ed. Churchill, London.

Kinnear, T. W. G. (1963). The pattern of diabetes mellitus in a Nigerian teaching hospital. E. Afr Med. J., 40, 288-294.

Klastskin, G., and Gordon, M. (1952). Relationship between relapsing pancreatitis and essential hyperlipemia. Amer. J. Med., 12, 3-23.

Laws, J. W., Shawdon, H., Booth, C. C., and Stewart, J. S. (1963). Correlation of radiological and histological findings in idiopathic steatorrhoea. Brit. med. J., 1, 1311-1314.

Leevy, M. C. (1962). Fatty liver: a study of 270 patients with biopsy proven fatty liver and a review of the literature. Medicine (Baltimore), 41, 249-278.

Lehmann, H. (1949). Haemogram, serum protein and plasma volume of healthy, well-nourished East Africans in Uganda. Nature (Lond.), 164, 954-955.

Leonard, P. J., and Banwell, J. G. (1964). The absorption of vitamin $A$ as an index of malabsorption in African subjects. E. $A f r$. med. J., 41, 501-504.

Limbos, P. (1956). Un cas de sprue tropicale provenant du Congo Belge. Ann. Soc. belg. Med. trop., 36, 151-158.

Magalhaes, Carvalho, Schmidt, M. M., and Pinto, A. G. (1947) Síndrome celiaca pós-distrofiá pluricarencial hidropigenica. J. Pédiat. (Rio de J.), 13, 141-151. Cited by Véghelyi, and Kemeny (1962).

McGuinness, A. C., and Gall, E. A. (1944). Mumps at army camps in 1943. War Med. (Chic.), 5, 95-104.

McMaster, D. N. (1962). A subsistence Crop Geography of Uganda. (World Land Use Survey. Occasional Papers, no. 2.) Geographical Publications, Bude.

Malins, J. M., and French, J. M. (1957). Diabetic diarrhoea. Quart. J. Med., 26, 467-480.

Manson-Bahr, P. H. (1943). Dysenteric Disorders, 2nd ed. Cassell, London.

Merkatz, I. R. (1961). Parotid enlargement resulting from excessive ingestion of starch. New Engl. J. Med., 265, 1304-1306.

Merlihot, J. (1963). Quelques observations de pancréatites chroniques à Madagasgar. Méd. trop., 23, 52-62.

Meynell, M. J., Cooke, W. T., Cox, E. V., and Gaddi, R. (1957). Serum-cyanocobalamin level in chronic intestinal disorders. Lancet, 1, 901-904.

Miller, J. R. M. (1951). Pancreatitis: Nyanza clinical meeting. E. Afr. med. J. 28, 386-387.

Milner, P, F., Irvine, R. A., Barton, C. J., Bras, G., and Richards, R.
(1965). Intestinal malabsorption in Strongyloides stercoralis infestation. Gut, 6, 574-581.

Montgomery, R. D. (1965). The medical significance of cyanogen in plant foodstuffs. Amer. J. clin. Nutr., 17, 103-113.

Normet, L .(1926). La "aboufissure d'Annam." Bull. Soc. pat. exot.19, 207-213. Cited by Trowell et al. (1954).

Owens, J. L., Jr., and Howard, J. M. (1958). Pancreatic calcification; a late sequal in the natural history of chronic alcoholism and alcoholic pancreatitis. Ann. Surg., 147, 326-338.

Ower, R. (1964). Gallstones in the autopsy population at Mulago hospital, Kampala. E. Afr. med. J., 41, 251-253.

Paterson, D. E., David, R., and Baker, S. J. (1965). Radiodiagnositic problems in malabsorption. Brit. J. Radiol., 38, 181-191.

Perrier, C. V. (1964). Symposium on the etiology and pathological anatomy of chronic pancreatitis: Marseilles, 1963. Amer. J. dig. Dis., 9, 371-376.

Ratnaike, V. T., and Rajasuriya, K. (1963). Pancreatic calcification, related to protein malnutrition. Trop. geogr. Med., 15, 1-6.

Richards, A. I. (1954). Economic Development and Tribal Change. A Study of Immigrant Labour in Buganda. Published for East African Institutue of Social Records by Heffer, Cambridge.

Ridley, D. S., and Hawgood, B. C. (1956). The value of formol-ether concentration of faecal cysts and ova. J. clin Path., 9, 74-76.

Santini, R., Jr., Sheehy, T. W., and Martinez-de Jesus, J. (1961). The xylose tolerance test with a five-gram dose. Gastroenterology, 40, 772-774.

Schilling, R. F. (1953). A new test for Intrinsic factor activity. J. Lab. clin. Med., 42, 946-947.

Schoental, R., and Magee, P. N. (1957). Chronic liver changes in rats after a single dose of lasiocarpine, a pyrrolizidine (Senecio) alkaloid. J. Path. Bact., 74, 305-319.

-, (1963). Liver disease and 'Natural' hepatotoxins. Bull. Wld Hlth Org., 29, 823-833.

Schweinburg, F., Jacob, S., Persky, L., and Fine, J. (1953). Further studies on the role of bacteria in death from acute pancreatitis in dogs. Surgery, 33, 367-369.

Scrimshaw, N. S., and Béhar, M. (1961). Protein malnutrition in young children. Science, 133, 2039-2047.

Shaper, A. G. (1959). Pancreatic fibrosis and calcification in Uganda Africans. Proc. nutr. Soc., 18, xxiii.

- (1960). Chronic pancreatic disease and protein malnutrition. Lancet, 1, 1223-1224.

-, (1961). Observations on the incidence and nature of chronic pancreatic disease in African diabetics in Uganda. Proc 4th Congr. int. Diabetes Fed., Geneva, 1, 119-122.

-, (1964). Aetiology of chronic pancreatic fibrosis with calcification seen in Uganda. Brit. med. J., 1, 1607-1609.

-, and Burkitt, D. P. (1962). Acute pancreatitis in childhood. Postgrad. med. J., 38, 704-706.

-, and Jones, K. W. (1959). Serum-cholesterol, diet, and coronary heart-disease in Africans and Asians in Uganda. Lancet, 2, 534-537.

-, Kyobe, K., and Stansfield, D. (1962). Haematological observations in an East African student population. E. Afr. med. J., 39, $1-4$.

-, and Patel, K. M. (1964). Diseases of the biliary tract in Africans in Uganda. Ibid., 41, 246-250.

and Shaper, L. (1958). Analysis of medical admissions to Mulago Hospital, 1957. E. Afr. med. J., 35, 647-678.

Stein, D. (1963). Pancreatitis-acute and relapsing - in infancy and childhood. S. Afr. med. J., 37, 1066-1072.

Thompson, M. D., and Trowell, H. C. (1952). Pancreatic enzyme activity in duodenal contents of children with a type of kwashiorker. Lancet, 1, 1031-1035.

Tiscornia, O. M., and Dreiling, D. A. (1966). Does the pancreatic gland regenerate? Gastroenterology, 51, 267-271.

Trowell, H. C. (1960). Non Infective Disease in Africa. Arnold, London, Davies, J. N. P., and Dean, R. F. A. (1954). Kwashiorkor. Arnold, London.

and Tropics. Arnold, London.

-, and Muwazi, E. M. K. (1945). A contribution to the study of malnutrition in Central Africa: a syndrome of malignant malnutrition. Trans. roy. Soc. trop. Med. Hyg., 39, 229-243.

Uganda Spirituous Liquor Commission Report (1963). Government Printers, Entebbe, Uganda.

Varley, H. (1962). Practical Clinical Biochemistry, 3rd ed. Heinemann, London.

Véghelyi, P. V. (1950). Nutritional edema. Ann. paediat. (Basel), 175, 349-377. 
Véghelyi H., and Kemeny, T. T. (1962). Protein metabolism and pancreatic function. In Ciba Foundation Symposium on The Exocrine Pancreas, edited by A. V. S. de Reuck and M. P. Cameron, pp. 329-352. Churchill, London.

Walker, A. R. P. (1949). Effect of low fat intakes and of crude fibre on the absorption of fat. Nature (Lond.), 164, 825-827.

Waters, A. H., and Mollin, D. L. (1961). Studies on the folic acid activity of human serum. J. clin. Path., 14, 335-344.

Watt, J. M., and Breyer-Brandwijk, M. G. (1962). The Medicinal and Poisonous Plants of Southern and Eastern Africa, 2nd ed. Livingstone, Edinburgh.
Wollaeger, E. E., Comfort, M. W., and Osterberg, A. E. (1947). Total solids, fat and nitrogen in the feces. III. A study of normal persons taking a test diet containing a moderate amount of fat; comparison with results obtained with normal persons taking a test diet containing a large amount of fat. Gastroenterology, 9, 272-283.

Wood, E. M., Snieszko, S. F., and Yasutake, W. T. (1955). Infectious pancreatic necrosis in brook trout. Arch. Path. (Chic.), 60, 26-28.

Zuidema, P. J. (1959). Cirrhosis and disseminated calcification of the pancreas in patients with malnutrition. Trop. geogr. Med., 11, 70-74. 